\title{
Combating Contagion and Injustice: The Shared Work for Public Health and Faith Communities During COVID-19
}

\author{
Joshua T. B. Williams ${ }^{1,2}$ (D) Adrian Miller ${ }^{3} \cdot$ Abraham M. Nussbaum $^{4,5}$
}

Accepted: 20 March 2021 / Published online: 27 March 2021

(c) The Author(s), under exclusive licence to Springer Science+Business Media, LLC, part of Springer Nature 2021

\begin{abstract}
Faith communities are uniquely positioned for essential public health work to combat the COVID-19 pandemic and address the chronic pre-existing health disparities that have been exacerbated by COVID-19. Specifically, faith communities can (1) dialogue with public health communities, developing internal policies and meeting guidelines consistent with evidence-based recommendations and their own faith traditions, (2) bolster religious daycare and parochial school immunization policies, and (3) partner with faith-based organizations through financial support and volunteer hours. This essential work will complement governmental public health approaches and ensure faith communities can assist with future pandemics.
\end{abstract}

Keywords Faith community $\cdot$ Public health · Vaccination · Clergy · Chaplains · COVID-19

\section{Introduction}

Encounters between medicine and religion can become pointed in a pandemic. When a church in South Korea was identified as an early site of COVID-19 transmission, its members were labeled as cult followers and its house of worship was characterized as a "petri dish" in the popular press (Yoon \& Martin, 2020). Over 1 year later, as US COVID-19 cases continue to mount, public

Joshua T. B. Williams

joshua.williams@dhha.org

1 Department of Pediatrics, Ambulatory Care Services, Denver Health Medical Center, 301 W 6th Avenue, MC 1911, Denver, CO 80204, USA

2 Department of Pediatrics, University of Colorado School of Medicine, Aurora, CO, USA

3 Colorado Council of Churches, Denver, CO, USA

4 Department of Behavioral Health, Denver Health Medical Center, Denver, CO, USA

5 Department of Psychiatry, University of Colorado School of Medicine, Aurora, CO, USA 
health workers, clinicians, and policymakers have turned their attention from schools, restaurants, and businesses, to the role religious gatherings play in this pandemic.

The Centers for Disease Control and Prevention have offered recommendations for communities of faith, but their suggestions are optional; communities can accept, reject, or modify them consistent with their beliefs ("Considerations for Communities of Faith" 2020). This option leaves many faith communities with a prudential decision for which they lack sufficient counsel, struggling to craft policies which simultaneously protect public health while publicly worshiping. Unfortunately, even worship is politicized. In an article published after President Donald Trump called on governors to immediately re-open houses of worship, reporters called out churches who defied lockdown orders and blamed the death of a 17 year-old girl on a church event (Conger et al., 2020). These encounters between medicine and religion have become legal conflicts, even extending up to the Supreme Court, between faith and public health officials (Parmet, 2021).

Beyond general guidelines and partisanship, how can public health and faith communities proceed in their shared essential work of helping communities flourish during COVID-19?

Long-term blanket prohibitions against meeting are inappropriate and intrusive. Sustained prohibitions undermine the essential role participating in a faith community plays in improving physical, emotional, and spiritual well-being at a time when wellness is elusive (Shanshan et al., 2016) and erode the social solidarity faith communities create and public health officials rely upon during a pandemic. Demands to immediately reinstate religious gatherings are equally inappropriate. Major faith traditions emphasize the good of a community as often they speak to the individual good. Few communities are likely to reopen without considering how best to protect the communities in which they gather as well as the health of their congregants. These considerations are especially important in light of the injustices COVID-19 has exploited.

\section{Combating Contagion and Injustice}

As an academic pediatrician who researches vaccination and religion, the first African-American Executive Director of a statewide faith-based organization, and a scholar of medicine and religion, we believe faith communities are unique partners for essential public health work during our COVID-19 pandemic and beyond. Throughout history, faith communities and faith leaders have undertaken indispensable work to seek the good of their communities during contagions (Levin, 2020; Williams \& Nussbaum, 2018). In this latest pandemic, we believe opportunities exist for faith communities to gather responsibly while simultaneously working to promote public health and tangibly demonstrate the 
common concern all faith communities share for the poor, the underserved, and the neglected.

What might they be?

\section{Dialogue with Public Health Communities to Develop Policies Consistent with Evidence-Based Recommendations and Faith Traditions}

First, faith and public health communities should enter dialogue where they recognize each others' domains of expertise. Public health officials could recognize that faith is a social determinant of population health by engaging faith communities as partners who provide social leadership, build solidarity, and develop the capacity to serve others (Idler et al., 2019). Faith communities could recognize the expertise of public health officials by translating evidence-based recommendations, such as those offered by the Centers for Disease Control and Prevention, into internal policies and enforcing adherence to them ("Considerations for Communities of Faith," 2020).

While many have emphasized the division of church and state, the lived experience of most communities is that church and state are always in dialogue. Faith communities should respect the advice which national, state, and local public health officials have the expertise and authority to offer and public health officials should reciprocate that respect. After all, faith communities are comprised of community members and operate within geographic boundaries. In any pandemic, every faith community will have persons suffering from disease as well as persons who are essential workers tasked with responding to it.

Faith communities can support the patients and workers in their communities through prayers and blessings but also through measures which reduce the risk of infection. Most faith communities have liturgies and/or ritual performances, which could incorporate hand hygiene, mask-wearing, and social-distancing requirements during services to demonstrate social solidarity. To further support social solidarity, faith communities could rigorously clean, disinfect, and ventilate buildings before and after worship. When technology allows, faith communities could use on-line sign-up sheets to limit the number of attendees in accordance with local requirements and encourage staff and congregants with high-risk conditions or in vulnerable groups to worship remotely. Congregations who gather in single, large services might choose to pursue multiple smaller gatherings separated in time (i.e., for appropriate disinfecting) or a hybrid model of in-person and on-line worship, and they could appeal to the endurance of faith communities across time and space as a way to explain such hybrid services.

To prevent the spread of COVID-19 through children, faith communities could discontinue large-scale nursery and child services, instead inviting children to services with their parents, or limiting attendance for concomitant educational gatherings and holding them outside or inside in accordance with social distancing recommendations. While very young children (i.e., age 2 years or under) may struggle to wear masks consistently, children are heavily influenced by what is normative; 3-4 year-olds will have little difficulty wearing a mask for 30 minutes if they are 
doing so because their leaders encourage them and their peers are also wearing them.

Myriad other questions will require the attention of clergy, chaplains, and staff, and policies and guidelines may not address them. What to do about social hours before or after service? How to distribute holy food prepared for religious services? Where to place musicians or worship leaders who play, sing, or speak? What to do if a congregant becomes sick after attending service? What to do if a congregant spent time with someone who was sick last week? To address these and many others, religious leaders should seek out congregants with formal health training (e.g., parish nurses, physicians, public health workers) for nuanced insights into specific questions.

These discussions will not be concluded at single points in time but will be ongoing dialogues, informed by local COVID-19 epidemiology, vaccine development, and the ever-changing implications disease transmission has for congregants and communities. Exemplars for doing so include Emory's Model Practices to Increase Influenza Prevention Among Hard-to-Reach Populations (Kiser \& Lovelace, 2019). Dialogue takes time and effort, and it may seem daunting for faith leaders and public health officials; both groups often find themselves understaffed and underpaid. To alleviate the burden of this work on clergy or chaplains and its interference with other religious duties, faith communities could appoint a COVID-19 lead person or team-preferably one with members with formal health training - to provide updates and guide congregants in relevant conversations. This group or individual could also monitor adherence to recommendations, liaison with public health officials, and provide feedback between the two groups. As trusted messengers, clergy and chaplains will play a critical role in this dialogue.

While these considerations are crucial to improve public health, they are equally key to fighting injustice. COVID-19 has disproportionately affected Black, Hispanic, and Indigenous Americans, and researchers have attributed COVID-19-associated health disparities to crowded urban areas and high rates of underlying comorbidities in minority groups (Webb Hooper et al., 2020). Religious gatherings have the potential to further exacerbate this injustice if congregations comprised principally of minorities who have high rates of underlying comorbidities gather frequently without proper precautions. US data on religious affiliation and religious service attendance by race and ethnicity suggest this is a real risk.

African-Americans, referent to other racial and ethnic groups, are more likely to report a formal religious affiliation (87\%), and over half are estimated to attend religious services at least once per week ("A Religious Portrait of African-Americans," 2009). Faith communities of color should recognize this difficult tension and strive to balance the benefits and freedoms of religious gatherings with the inherent individual and corporate risk of doing so. Likewise, public health officials should recognize the critical role that faith communities play in developing social solidarity and personal well-being. As first steps, like all faith communities, those of color can dialogue with public health officials to develop guidelines consistent with evidence-based recommendations and that reflect the nuances of their faith tradition. 


\section{Strengthen Religious School, Daycare, and Parochial School Immunization Requirements}

Second, as both public health and faith communities are invested in children, they could partner to develop and strengthen religious school, daycare, and parochial school immunization policies to limit the spread of COVID-19 and other vaccinepreventable diseases. As COVID-19 first spread through the US, it disrupted vaccine delivery to young children as parents forewent well child checks and as practices furloughed clinicians or closed altogether. From March to April 2020, orders for non-influenza vaccines through the Vaccines for Children program decreased by 2,500,000 doses year-over-year (Santoli et al., 2020). During the same time frame, at eight managed care organizations within the Vaccine Safety Datalink, 200,000 fewer children received measles-containing vaccines, compared to the year prior (Santoli et al., 2020). The effect of COVID-19 on routine immunization delivery has been enormous, increasing the risk of outbreaks of diseases like measles and pertussis in our communities in coming months and years.

Historically, requiring children to receive selected vaccines prior to public school or daycare entry has been an effective method for preventing such disease outbreaks (Orenstein \& Hinman, 1999). All states currently have laws requiring vaccines for school or daycare entry ("States with Religious and Philosophical Exemptions from School Immunization Requirements," 2020). However, 45 states and the District of Columbia offer exemptions to school-mandated vaccines on religious grounds, even though major religions support vaccination (Grabenstein, 2013), and over a dozen states allow exemptions for philosophical reasons ("States with Religious and Philosophical Exemptions from School Immunization Requirements," 2020). Millions of American children attend parochial and other private religious schools ("Private School Enrollment," 2020), and studies suggest private schools have higher rates of exemptions to school immunization requirements than public schools, with over twice the rate of religious exemptions specifically (Shaw et al., 2014). Additionally, rates of religious exemptions appear to be increasing; among kindergartners, religious exemptions increased significantly from 2011 to 2018, despite a simultaneous decrease in American religiosity (Williams, et al., 2019a). Many suspect these trends indicate misuse of religious vaccine exemptions for children by parents without religious objections to vaccines or even a genuine religious affiliation.

This rise in religious exemptions, and their high rates within private schools, compound existing COVID-19-induced immunization problems, pose a problem to COVID-19 vaccine distribution, and threaten child and community health. Multiple studies have linked exemption availability and high exemption rates to outbreaks of infectious diseases, including measles and pertussis (Feikin et al., 2000; Phadke et al., 2016). As a result, in recent years, policymakers have tried to eliminate religious or philosophical vaccine exemptions at the state level to increase vaccination coverage rates ("Update on top 10 resolutions adopted at Annual Leadership Forum," 2019). Yet, the process is difficult, and anti-vaccination groups have stalled or doomed efforts on several occasions (Tully et al., 2020). 
In lieu of attempting to change policy at the state level, religious schools and daycares could avert thousands of illnesses and save lives simply by refusing to accept religious exemptions at the level of their own institution. Many have already done so. In 2014, the Catholic Bishop of Orlando, FL-in charge of 79 parishes, 11 missions, two Basilicas, 43 schools, and hundreds of ministries-stopped recognizing religious vaccine exemptions in parochial schools (Noonan, 2014). In 2019, the Archdiocese of Seattle-representing 73 Catholic schools, 144 parishes, and nearly 1 million members-followed suit, referencing official teaching by the Pontifical Academy for Life and the moral obligation in Catholicism to guarantee the safety of others through vaccination ("School Immunization Policy Updated to Reflect Catholic Teaching," 2019).

These decisions impacted hundreds of thousands of children and their communities, and they were accomplished quickly, independent of state policies permitting exemptions that may have been more difficult to change. They are examples of how powerful the partnership between public health and faith communities can be. They are also an excellent example of religious leaders engaging their communities and leaning more deeply into their sacred texts and teachings to develop and implement policies consistent with their beliefs.

Furthermore, as we disseminate COVID-19 vaccines, religious leaders could replicate this behavior by organizing gatherings for their community members to reflect more deeply upon their sacred texts and teachings and the ways they interact with the topic of vaccines (COVID-19 or otherwise). Leaders could use materials published in the academic literature, such as John Grabenstein's 2013 review of "What the World's Religions Teach, Applied to Vaccines and Immunoglobulins" (Grabenstein, 2013), as well as other materials-e.g., letters, blog posts, or pamphlets—from individual leaders (Noonan, 2014) or other authoritative bodies within their own tradition, ("School Immunization Policy Updated to Reflect Catholic Teaching," 2019). This work, especially if it addresses school-attendance requirements, routine childhood vaccinations (e.g., measles, influenza, and pertussis), and COVID-19, will be essential when COVID-19 vaccines are available for schoolchildren. Strengthening religious school and daycare vaccination policies will not only protect children and families attending those schools but extend the benefits of herd immunity to disadvantaged community members who lack healthcare access or face obstacles to making appointments.

Herd immunity, or community immunity, exists when sufficient people in a community are protected against an infectious disease that it becomes hard for the causative bacteria or virus to find susceptible individuals. Importantly, herd immunity can have collateral benefits. For example, when a vaccine against a bacteria that causes ear infections in children was introduced in the US, the number of older adults hospitalized for bacterial pneumonia declined ("Vaccines Protect Your Community," 2020). For decades, poor and minority children have lagged behind wealthier and white counterparts in vaccination coverage (Bobo et al., 1993; Miller et al., 1994). Multi-level barriers, such as limited transportation, appointment times that conflict with work schedules, and chaotic home environments for single parents contribute to vaccination disparities (Lannon et al., 1995). Strengthening school or daycare vaccination policies will not directly address these determinants, but it will improve 
herd immunity. In turn, herd immunity will protect disadvantaged community members who face numerous obstacles to vaccination and give them additional time and opportunities to receive recommended vaccines.

\section{Partner with and Financially Support Faith-Based Organizations}

Finally, faith communities could partner with and financially support ecumenical, faith-based organizations who promote public health and pursue justice. While many of these organizations exist in the form of local, regional, and national Departments of Public Health, faith-based, ecumenical organizations are dedicated to working across denominational lines to promote health and combat injustices. Leaders network throughout states, identify community priorities through stakeholder engagement, and work to allocate resources to meet needs and promote unity and well-being.

Our own state's Colorado Council of Churches (CCC) is a collaboration of thirteen Christian denominations representing over 800 different congregations across the entire state. In 2019, the CCC partnered with Denver Health Medical Center and the University of Colorado to co-host vaccination listening circles in Denver-area faith communities through a community-based participatory research grant from the National Center for Advancing Translational Sciences (Williams et al., 2019b, 2020). Our partnership allowed dozens of congregants from diverse faith traditions to voice concerns in a safe atmosphere with trusted peers and clergy present and receive answers from a licensed physician. In 2020, the CCC received a grant from the Colorado Department of Local Affairs to outreach vulnerable, hard-to-count persons for the 2020 Census. In so doing, it increased the response rate from community members in rural and disadvantaged areas, ensuring that minority and hard-toreach communities would receive federal funding commensurate with their needs.

Today, the CCC is establishing diverse partnerships to mitigate COVID-19 transmission and advance justice. It will continue to collaborate with local vaccination experts to host COVID-19 vaccine listening circles at African American faith communities in 2021-2022, funded by ongoing support from the National Center from Advancing Translational Sciences. On a national scale, such partnerships in the pursuit of public health and health equity can be powerful. For example, in 2009, a collaboration between the Interfaith Health Program at Emory University, various Departments of Public Health, and many faith-based organizations around the country helped deliver 13,000-20,000 doses of H1N1 influenza vaccine during our last US pandemic (Kiser \& Lovelace, 2019). Importantly, the doses of vaccines were specifically delivered to hard-to-reach, vulnerable, and minority populations that may have otherwise been overlooked through traditional public health outreach and educational campaigns (Kiser \& Lovelace, 2019). The parallels for preventing COVID-19 circulation are clear. However, while key, these partnerships are difficult to form on large scales and require time, volunteers, and funding to maintain. Thus, faith communities could partner with and financially support ecumenical, faithbased organizations who are committed to public health and justice. 


\section{Conclusion: Combating Contagion and Injustice}

The encounter of medicine and religion can become painful or purposeful (Levin, 2020). Faith communities have a long history of assisting in public health responses to contagion (Miller \& Rubin, 2011); COVID-19 is the latest opportunity for public health officials to engage faith communities in a battle against an infectious disease. Faith communities can bolster the faith and health of their communities by sharing stories of such partnerships from their faith's past. Many of those examples will show how past pandemics have disproportionately affected the indigent, vulnerable, and marginalized. Today's COVID-19 pandemic similarly presents faith communities with an opportunity to address injustice.

Faith communities can pursue fruitful partnerships with public health communities, following after The Rollins School of Public Health's Interfaith Health Program or Wheaton College's Humanitarian Disaster Institute. Public health communities know how to track, treat, and prevent individual disease so they can improve population health. Faith communities have the unique authority, numbers, resources, and infrastructure to help public health agencies succeed while advancing social solidarity and justice. In dialogue together, faith communities can translate evidence-based recommendations into their practices, bolster school and daycare vaccination policies, and support faith-based organizations in the work they are already doing. This essential work will ensure public health and faith communities remain strong and diverse bodies, capable of assisting with the contagions of tomorrow, together.

Funding This was supported by NIH/NCATS Colorado CTSA Grant Number UL1 TR002535. Contents are the authors' sole responsibility and do not necessarily represent official NIH views.

\section{Declarations}

Conflict of interest All authors report no conflicts of interest relevant to this work.

Ethical Approval This manuscript is a commentary and, as such, was exempt from formal ethics approval by the Colorado Multiple Institutional Review Board.

\section{References}

A Religious Portrait of African-Americans. (2009). Pew research forum. https://www.pewforum.org/ 2009/01/30/a-religious-portrait-of-african-americans/. Accessed 20 July 2020.

Bobo, J. K., Gale, J. L., Thapa, P. B., \& Wassilak, S. G. F. (1993). Risk factors for delayed immunization in a random sample of 1163 children from Oregon and Washington. Pediatrics, 91(2), 308-314.

Conger, K., Healy, J., \& Topmkins, L. (2020). Churches were eager to reopen. Now they are confronting coronavirus cases. . New York Times.

Considerations for Communities of Faith. (2020). Centers for disease control and prevention. https:// www.cdc.gov/coronavirus/2019-ncov/community/faith-based.html?CDC_AA_refVal=https\%3A\% 2F\%2Fwww.cdc.gov\%2Fcoronavirus\%2F2019-ncov\%2Fphp $\% 2$ Ffaith-based.html. Accessed 14 July 2020 . 
Feikin, D. R., Lezotte, D. C., Hamman, R. F., Salmon, D. A., Chen, R. T., \& Hoffman, R. E. (2000). Individual and community risks of measles and pertussis associated with personal exemptions to immunization. Journal of the American Medical Association, 284(24), 3145-3150.

Grabenstein, J. D. (2013). What the World's religions teach, applied to vaccines and immune globulins. Vaccine, 31(16), 2011-2023. https://doi.org/10.1016/j.vaccine.2013.02.026.

Idler, E., Levin, J., VanderWeele, T. J., \& Khan, A. (2019). Partnerships between public health agencies and faith communities. American Journal of Public Health, 109(3), 346-347. https://doi.org/ 10.2105/AJPH.2018.304941.

Kiser, M., \& Lovelace, K. (2019). A national network of public health and faith-based organizations to increase influenza prevention among hard-to-reach populations. American Journal of Public Health, 109(3), 371-377. https://doi.org/10.2105/AJPH.2018.304826.

Lannon, C., Brack, V., Stuart, J., Caplow, M., McNeill, A., Bordley, W., \& Margolis, P. (1995). What mothers say about why poor children fall behind on immunizations. A summary of focus groups in North Carolina. Archives of Pediatrics and Adolescent Medicine, 149(10), 1070-1075.

Levin, J. S. (2020). Religion and medicine: A history of the encounter between humanity's two greatest institutions. (1st ed.). Oxford University Press.

Miller, A. N., \& Rubin, D. L. (2011). Health communication and faith communities. (1st ed.). Hampton Press.

Miller, L. A., Hoffman, R. E., Baron, A. E., Marine, W. M., \& Melinkovich, P. (1994). Risk factors for delayed immunization against measles, mumps, and rubella in Colorado two-year-olds. Pediatrics, 94(2I), 213-219.

Noonan, J. (2014). Immunization policy. Diocese of Orlando. https://www.orlandodiocese.org/ministriesoffices/schools/schools-parent-information/schools-immunization-policy/. Accessed 14 July 2020.

Orenstein, W. A., \& Hinman, A. R. (1999). The immunization system in the United States-The role of school immunization laws. Vaccine. https://doi.org/10.1016/S0264-410X(99)00290-X.

Parmet, W. E. (2021). Roman catholic diocese of Brooklyn v. Cuomo-The supreme court and pandemic conrtols. The New England Journal of Medicine., 384, 199-201.

Phadke, V. K., Bednarczyk, R. A., Salmon, D. A., \& Omer, S. B. (2016). Association between vaccine refusal and vaccine-preventable diseases in the United States: A review of measles and pertussis. JAMA Journal of the American Medical Association, 315(11), 1149-1158. https://doi.org/10.1001/ jama.2016.1353.

Private School Enrollment. (2020). National center for educational statistics. https://nces.ed.gov/progr ams/coe/indicator_cgc.asp. Accessed 14 July 2020.

Santoli, J. M., Lindley, M. C., DeSilva, M. B., Kharbanda, E. O., Daley, M. F., Galloway, L., et al. (2020). Effects of the COVID-19 pandemic on routine pediatric vaccine ordering and administrationUnited States. MMWR Morbidity and Mortality Weekly Report, 69(19), 591-593. https://doi.org/10. 15585/mmwr.mm6919e2.

School Immunization Policy Updated to Reflect Catholic Teaching. (2019). Northwest catholic. https:// www.nwcatholic.org/news/local/school-immunization-policy-updated-to-reflect-catholic-teaching. html. Accessed 12 August 2020.

Shanshan, L., Stampfer, M. J., Williams, D. R., VanderWeele, T. J., \& Chan, H. T. (2016). Religious service attendance and mortality among women Hhs. JAMA Internal Medicine, 176(6), 777-785. https://doi.org/10.1001/jamainternmed.2016.1615.

Shaw, J., Tserenpuntsag, B., McNutt, L.-A., \& Halsey, N. (2014). United States private schools have higher rates of exemptions to school immunization requirements than public schools. Journal of Pediatrics, 165(1), 129-133.

States with Religious and Philosophical Exemptions from School Immunization Requirements. (2020). National conference of state legislatures. https:/www.ncsl.org/research/health/school-immunizati on-exemption-state-laws.aspx.

Tully, T., Otterman, S., \& Hoffman, J. (2020). how anti-vaccine activists doomed a bill in New Jersey. New York Times. https://www.nytimes.com/2020/01/16/nyregion/nj-vaccinations-religious-exemp tion.html.

Update on top 10 resolutions adopted at Annual Leadership Forum. (2019). American academy of pediatrics. https://www.aappublications.org/news/2019/07/02/alf070219. Accessed 2 February 2020.

Vaccines Protect Your Community. (2020). U.S. department of health and human services. https://www. vaccines.gov/basics/work/protection. Accessed 12 August 2020.

Webb Hooper, M., Napoles, A. M., \& Perez-Stable, E. J. (2020). COVID-19 and racial/ethnic disparities. JAMA, 323(24), 2466-2467. https://doi.org/10.1002/jclp.20757. 
Williams, J. T. B., Miller, A., \& O'Leary, S. T. (2020). Sacred or secular? Exploring religious coloradans questions about vaccines. Vaccine, 38(45), 6971-6974.

Williams, J. T. B., \& Nussbaum, A. M. (2018). Minister to their instruction: Revisiting the ministervaccinator rowland hill. Pediatrics, 142(6), e20181021. https://doi.org/10.1542/peds.2018-1021.

Williams, J. T. B., Nussbaum, A. M., \& O'Leary, S. T. (2019a). Building trust: Clergy and the call to eliminate religious exemptions. Pediatrics. https://doi.org/10.1542/peds.2019-0933.

Williams, J. T. B., Rice, J., Cox-Martin, M., Bayliss, E. A., \& O’Leary, S. T. (2019b). Religious vaccine exemptions in kindergartners: 2011-2018. Pediatrics, 144(6), e20192710. https://doi.org/10.1542/ peds.2019-2710.

Yoon, D., \& Martin, T. W. (2020). Why a South Korean church was the perfect petri dish for coronavirus. The Wall Street Journal. https:/www.wsj.com/articles/why-a-south-korean-church-was-the-perfectpetri-dish-for-coronavirus-11583082110.

Publisher's Note Springer Nature remains neutral with regard to jurisdictional claims in published maps and institutional affiliations. 